\title{
Modified Exponential-rational Methods for the Numerical Solution of First Order Initial Value Problems
}

(Kaedah Eksponen-Nisbah Terubah Suai bagi Penyelesaian Masalah Nilai Awal Peringkat Pertama Secara Berangka)

\author{
TEH YUAN YING*,ZURNI OMAR \& KAMARUN HIZAM MANSOR
}

\begin{abstract}
Exponentially-fitted numerical methods are appealing because L-stability is guaranteed when solving initial value problems of the form $y^{\prime}=\lambda y, y(a)=\eta, \lambda \in \mathbb{C}, \operatorname{Re}(\lambda)<0$. Such numerical methods also yield the exact solution when solving the above-mentioned problem. Whilst rational methods have been well established in the past decades, most of them are not 'completely' exponentially-fitted. Recently, a class of one-step exponential-rational methods (ERMs) was discovered. Analyses showed that all ERMs are exponentially-fitted, hence implying L-stability. Several numerical experiments showed that ERMs are more accurate than existing rational methods in solving general initial value problem. However, ERMs have two weaknesses: every ERM is non-uniquely defined and may return complex values. Therefore, the purpose of this study was to modify the original ERMs so that these weaknesses will be overcome. This study discusses the generalizations of the modified ERMS and the theoretical analyses involved such as consistency, stability and convergence. Numerical experiments showed that the modified ERMs and the original ERMs are found to have comparable accuracy; hence modified ERMs are preferable to original ERMS.
\end{abstract}

Keywords: Exponential function; initial value problem; modified exponential-rational method; problem whose solution possesses singularity; rational function

\section{ABSTRAK}

Kaedah berangka yang bersesuaian secara eksponen adalah menarik kerana kestabilan L adalah terjamin apabila menyelesaikan masalah nilai awal yang berbentuk $y^{\prime}=\lambda y, y(a)=\eta, \lambda \in \mathbb{C}, \operatorname{Re}(\lambda)<0$. Kaedah berangka yang sedemikian juga menghasilkan penyelesaian tepat apabila menyelesaikan masalah yang dinyatakan sebelum ini. Walaupun kaedah nisbah telah menjadi mantap dalam beberapa dekad yang lalu, sebahagian besar daripada kaedah ini tidak bersesuaian secara eksponen sepenuhnya. Baru-baru ini, suatu kelas kaedah eksponen-nisbah satu-langkah (ERM) telah ditemui. Beberapa analisis menunjukkan bahawa semua ERM adalah bersesuaian secara eksponen, maka mengimplikasikan kestabilan L. Beberapa pengujian berangka menunjukkan bahawa ERM adalah lebih tepat berbanding dengan kaedah nisbah yang sedia ada dalam menyelesaikan masalah nilai awal umum. Walau bagaimanapun, ERM mempunyai dua kelemahan: setiap ERM tidak ditakrifkan secara unik dan boleh mengembalikan nilai-nilai yang kompleks. Oleh itu, tujuan kajian ini adalah untuk mengubah suai ERM yang asal supaya kelemahan tersebut dapat diatasi. Kajian ini membincangkan pengitlakan bagi ERM yang diubah suai dan analisis teori yang terlibat seperti kekonsistenan, kestabilan dan penumpuan. Pengujian secara berangka menunjukkan bahawa ERM yang telah diubah suai dan ERM yang asal didapati mempunyai ketepatan yang setara; maka ERM yang diubah suai lebih sesuai berbanding dengan ERM yang asal.

Kata kunci: Fungsi eksponen; fungsi nisbah; kaedah eksponen-nisbah diubah suai; masalah dengan penyelasaian yang mempunyai ketunggalan; masalah nilai awal

\section{INTRODUCTION}

We consider the numerical solution of the initial value problem

$$
y^{\prime}(x)=f(x, y), y(a)=\eta
$$

If the solution of (1) is known to be periodic or oscillate with a known frequency, then a numerical integration formulae based on trigonometric functions is appropriate (Lambert 1973). On the other hand, if the solution of (1) possesses singularities, then a numerical integration formulae based on rational functions will be much more effective. In both cases, unconventional methods are preferable as they adapt to the structure or to the solution of the problem better than conventional methods. Unconventional methods are special numerical methods which are developed to solve certain types of initial value problems, where in the main, conventional methods such as linear multistep methods and RungeKutta methods will perform poorly. Besides incorporating trigonometric functions and rational functions as nonpolynomial interpolants to form new special methods, 
other commonly used non-polynomial interpolants are logarithmic and exponential functions.

Among the special numerical methods based on non-polynomial interpolants mentioned above, we are particularly attracted to special numerical methods based on rational functions. We refer to these kind of methods as rational methods. For excellent surveys and various perspectives on rational methods, refer to Fatunla (1982, 1986), Ikhile (2004, 2002, 2001), Lambert (1974), Lambert and Shaw (1965), Luke et al.(1975), Okosun \& Ademiluyi (2007a, 2007b), Ramos (2007), Teh et al. (2011, 2009), Teh \& Yaacob (2013a, 2013b), van Niekerk (1988, 1987), Wambecq (1976) and Yaacob et al. (2010).

All the works mentioned have discussed various formulations of one-step rational methods as well as some rational methods in a multistep setting that are based on various forms of rational interpolants. These rational interpolants possess either both numerator and denominator being polynomial expressions or only one of them is a polynomial expression. However, Teh and Yaacob (2013b) suggested that the incorporation of exponential function into conventional rational function to form a new kind of rational interpolant in developing a rational method with special properties. The resulting methods are rational methods that are exponentially-fitted because they yield exact solutions when solving the problem

$$
y^{\prime}=\lambda y, y(a)=\eta, \lambda \in \mathbb{C}, \operatorname{Re}(\lambda)<0 .
$$

These exponentially-fitted methods are known as onestep exponential-rational methods (ERMs), which suggest an approximation to the theoretical solution of (1) at $x_{n+1}$ is given by

$$
y_{n+1}=\frac{\sum_{i=0}^{k} a_{i} h^{i}+c_{1} e^{c_{2} h}}{1+b h}, 1+b h \neq 0,
$$

where $b, c_{1}, c_{2}$ and $a_{j}$ for $j=0,1, \ldots, k$ are parameters that may contain $y\left(x_{n}\right)$ and higher derivatives of $y\left(x_{n}\right)$. Note that $a_{j}=0$ if $k$ is set to 0 . If an ERM has order $p$, then this particular ERM is called a $p$-ERM. Teh and Yaacob (2013b) developed ERMs of order orders 3 and 4, together with their respective local truncation errors and stability functions. Stability analyses had showed that all ERMs developed are $L$-stable. Furthermore, all ERMs proposed were compared numerically with those existing rational methods in the articles mentioned above, using some test problems. Numerical results showed that almost all ERMs gave more accurate numerical solutions in solving (1).

Despite the strong stability characteristics and better accuracies of ERMs in (3), there are two shortcomings of ERMs. Firstly, there are actually two different ERMs for each order of accuracy due to the fact that two different expressions of $c_{2}$ emerged during the derivation process (Teh \& Yaacob 2013b). In other words, a $p$-th order ERM is not unique but two different methods. At this moment, no criterion or condition has been devised to determine which ERM is better for the same order of accuracy. Secondly, the parameter $c_{2}$ of each ERM in (3) may contain an expression with square root. In other words, there are times where ERM will produce numerical solutions that are complex numbers due to the square root evaluations of the parameter $c_{2}$. In order to retrieve numerical solutions that are only real numbers, Teh and Yaacob (2013b) chose to consider the real parts of the resulting complex values and ignored the imaginary parts of the complex values that were found numerically to be very small. However, by ignoring the imaginary parts of the complex values will somehow affect the degree of accuracy of the numerical solutions. These two disadvantages of ERM become the main rationales of this study, where we wish to modify the original ERM in (3), so that the newly modified ERMs are free from the two defects mentioned before. The developments and implementations of the new modified ERMs will be presented in the following sections.

\section{PRELIMINARIES}

We are considering the initial value problem in (1), where $y, f(x, y) \in \mathbb{R}, x \in[a, b] \subset \mathbb{R}$, and $f(x, y)$ is assumed to satisfy all the conditions in order that (1) has a unique solution. The interval $[a, b]$ is divided into a number of subintervals $\left[x_{n}, x_{n+1}\right]$ with $x_{0}=a$ and $x_{n}=x_{0}+n h$, such that $h$ is the step-size. Suppose that we have solved numerically the initial value problem in (1) up to a point $x_{n}$ and have obtained a value $y_{n}$ as an approximation of $y\left(x_{n}\right)$, which is the theoretical solution of (1). From Lambert (1991, 1973), assuming the localizing assumption that no previous truncation errors have been made, i.e. $y_{n}=y\left(x_{n}\right)$, we are interested in obtaining $y_{n+1}$ as the approximation of $y\left(x_{n+1}\right)$. For that purpose, we suggest an approximation to the theoretical solution $y\left(x_{n+1}\right)$ of (1) given by

$$
y_{n+1}=\frac{\sum_{j=0}^{k} a_{j} h^{j}+c e^{\frac{h_{n}^{\prime}}{y_{n}}}}{1+b h}, 1+b h \neq 0, k=0,1,2, \ldots
$$

where $b, c$ and $a_{j}$ for $j=0,1, \ldots, k$ are parameters that may contain $y\left(x_{n}^{j}\right)$ and higher derivatives of $y\left(x_{n}\right)$ and $h$ is the step-size. In view of this, these parameters have to be determined during the derivation process. The value $k$ presented in (4) decides the number of derivatives to be evaluated in (4) i.e. a total of $y^{(m)}\left(x_{n}\right)$ for $m=1,2, \ldots, k+2$. The higher the value of $k$, the more derivatives evaluations need to be carried out.

Formula (4) is the modified version of the original exponential-rational method shown in (3). One has noticed that the exponential functions in both (3) and (4) are different. The exponential function $e^{c_{2} h}$ from (3) is replaced by the exponential function $e^{h y_{n}^{\prime} / y_{n}}$ as shown in (4). This replacement was motivated by the work of $\mathrm{Wu}$ and Xia (2001) who suggested the exponential function $e^{h y_{n}^{\prime} / y_{n}}$ and used it to develop a one-step explicit numerical method for 
the numerical solution of (1). Satisfying numerical results were reported in Wu and Xia (2001).

We regard (4) as one-step modified exponentialrational method, or in brief as MERM. If a MERM has order $p$, then this particular MERM is called a $p$-MERM. With the $p$-MERM in (4), we associate a difference operator $L$ defined by

$$
\begin{aligned}
L[y(x) ; h]_{p-\operatorname{MERM}}= & y(x+h) \times(1+b h) \\
& -\sum_{j=0}^{k} a_{j} h^{j}-c e^{\frac{h y^{\prime}(x)}{y(x)}}, k \geq 0, p \geq 2 .
\end{aligned}
$$

where $y(x)$ is an arbitrary function, continuously differentiable on $x \in[a, b] \subset \mathbb{R}$. Expanding $y(x+h)$ and exponential function $e^{h y^{\prime}(x) / y(x)}$ as Taylor series and collecting terms in (5) gives the following general expression:

$$
\begin{aligned}
L[y(x) ; h]_{p \text {-MERM }}= & C_{0} h^{0}+C_{1} h^{1}+\ldots+C_{k} h^{k} \\
& +C_{k+1} h^{k+1}+C_{k+2} h^{k+2}+\ldots
\end{aligned}
$$

We note that $C_{i}, i=0,1,2, \ldots$ in (6) contains corresponding parameters that need to be determined in the derivation processes. To facilitate the derivation of MERM, the order and local truncation error of $p$-MERM are defined as follows.

Definition 1 The difference operator (5) and the associated modified exponential-rational method (4) is said to be of order $p=k+2$ if, in (6), $C_{0}=C_{1}=C_{2}=\ldots$ $=C_{k+2}=0, C_{k+3} \neq 0$ for $k=0,1,2, \ldots$.

Definition 2 The local truncation error at $x_{n+1}$ of (4) is defined to be the expression $L\left[y\left(x_{n}\right) ; h\right]_{p-\mathrm{MERM}}$ given by (5), when $y\left(x_{n}\right)$ is the theoretical solution of the initial value problem (1) at a point $x_{n}$. The local truncation error of (4) is then

$$
L\left[y\left(x_{n}\right) ; h\right]_{p \text {-MERM }}=C_{k+3} h^{k+3}+O\left(h^{k+4}\right) .
$$

From Definition 1, it is important to note that

$$
k=p-2,
$$

since we are going to use this expression in the remainder of this paper.

\section{DERIVATION OF ONE-STEP MODIFIED EXPONENTIAL- RATIONAL METHOD}

The derivation of one-step MERM is all about finding the unknown coefficients (parameters) $b, c$ and $a_{j}$ for $j=0,1$, $\ldots, k$ in formula (4). First, we must determine the desired order accuracy by setting an arbitrary value for $p$. Then, the value of $k$ can be obtained once the arbitrary value of $p$ is determined using (8). Next, from (5), we have to expand $y(x+h)$ and $e^{h y^{\prime}(x) / y(x)}$ as Taylor series and also expand the polynomial $\sum_{j=0}^{k} a_{j} h^{j}$ up to degree $k$. After that, we must arrange the expanded (5) until (6) is achieved Upon comparison between the expanded (5) and (6), we can identify the expressions which correspond to $C_{0}, C_{1}$, $\ldots, C_{1+2}$ and $C_{1+3}$. Finally, with $C_{0}=C_{1}=\ldots=C_{1+2}=0$, and taking $y(x)$ as the theoretical solution of the initial value problem (1) i.e. $y(x)=y\left(x_{n}\right)$, we can obtain a system of $k$ +2 simultaneous equations as shown next.

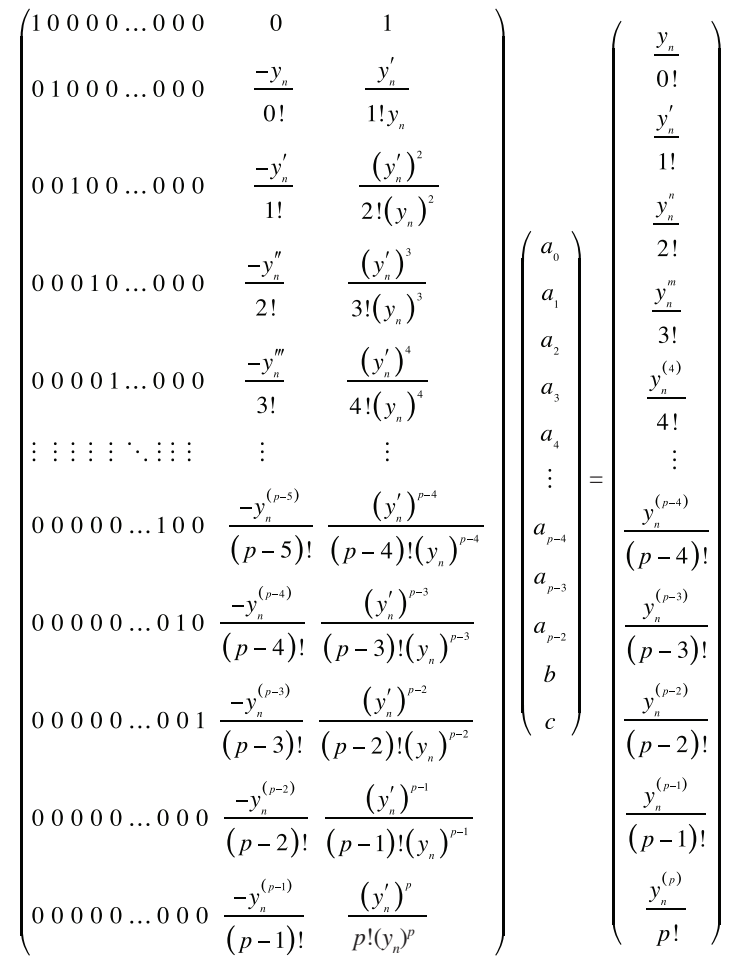

The system of equations in (9) is used to determine the unknown coefficients $b, c$ and $a_{j}$ for $j=0,1, \ldots, k$. These coefficients, in fact, facilitate a generalization of MERMs of arbitrary order $p$. In other words, the coefficients can be computed once the desired order of accuracy $(p)$ is determined. On solving the system (9) for the unknown coefficients $b, c$ and $a_{j}$ for $j=0,1, \ldots, k$ using MATHEMATICA 8.0 software, we obtain the following generalized formulae:

$$
a_{0}=y_{n}+\frac{\left(y_{n}\right)^{p}\left(y_{n}^{\prime}\right)^{1-p}\left[(p-2) ! p !\left(y_{n}^{(p-1)}\right)^{2}-((p-1) !)^{2} y_{n}^{(p-2)} y_{n}^{(p)}\right]}{((p-1) !)^{2} y_{n}^{\prime} y_{n}^{(p-2)}-(p-2) ! p ! y_{n} y_{n}^{(p-1)}},
$$

$$
\begin{aligned}
a_{j}= & \left(y_{n}\right)^{-j}\left(y_{n}^{\prime}\right)^{-p}\left[-j !(p-2) !(p-1) !\left(y_{n}\right)^{j}\left(y_{n}^{\prime}\right)^{p+1} y_{n}^{(j-1)} y_{n}^{(p-1)}\right. \\
& +j !(p-2) !(p-1) !\left(y_{n}\right)^{j+1}\left(y_{n}^{\prime}\right)^{p} y_{n}^{(j-1)} y_{n}^{(p)} \\
& +(j-1) !\left(y_{n}\right)^{p}\left(y_{n}^{\prime}\right)^{j+1}\left((p-2) ! p !\left(y_{n}^{(p-1)}\right)^{2}\right. \\
& \left.\left.-((p-1) !)^{2} p ! y_{n}^{(p-2)} y_{n}^{(p)}\right)\right] / \\
& \left((j-1) ! j !\left[((p-1) !)^{2} y_{n}^{\prime} y_{n}^{(p-2)}-(p-2) ! p ! y_{n} y_{n}^{(p-1)}\right]\right),
\end{aligned}
$$




$$
b=\frac{(p-2) !(p-1) !\left(y_{n}^{\prime} y_{n}^{(p-1)}-y_{n} y_{n}^{(p)}\right)}{-((p-1) !)^{2} y_{n}^{\prime} y_{n}^{(p-2)}+(p-2) ! p ! y_{n} y_{n}^{(p-1)}},
$$

and

$$
c=\frac{\left(y_{n}\right)^{p}\left(y_{n}^{\prime}\right)^{1-p}\left[(p-2) ! p !\left(y_{n}^{(p-1)}\right)^{2}-((p-1) !)^{2} y_{n}^{(p-2)} y_{n}^{(p)}\right]}{-((p-1) !)^{2} y_{n}^{\prime} y_{n}^{(p-2)}-(p-2) ! p ! y_{n} y_{n}^{(p-1)}},
$$

where $y_{n}=y\left(x_{n}\right)$ and $y_{n}^{(m)}=y^{(m)}\left(x_{n}\right)$ for $j=1,2, \ldots, k, p=k$ +2 and $m=1,2, \ldots, p$ by the localizing assumption. We note that formulae (4) and (10) - (13) are valid provided that $y_{n}=y\left(x_{n}\right) \neq 0$.

\section{LOCAL TRUNCATION ERROR OF MODIFIED EXPONENTIAL- RATIONAL METHOD}

In the process of identifying the expressions which correspond to $C_{0}, C_{1}, \ldots, C_{1+2}$ and $C_{1+3}$ and taking $y(x)$ as the theoretical solution of the initial value problem (1) i.e. $y(x)=y\left(x_{n}\right)$, we found that

$$
C_{k+3}=-\frac{c\left(y_{n}^{\prime}\right)^{p+1}}{(p+1) !\left(y_{n}\right)^{p+1}}+\frac{b y_{n}^{(p)}}{p !}+\frac{y_{n}^{(p+1)}}{(p+1) !}
$$

for arbitrary value of $p$ (or arbitrary value of $k$ ). Therefore, from Definition 2, the local truncation error (in brief as LTE) of a $p$-MERM (4) is given by

$$
\begin{aligned}
\operatorname{LTE}_{p-\text { MERM }}= & h^{p+1}\left(-\frac{c\left(y_{n}^{\prime}\right)^{p+1}}{(p+1) !\left(y_{n}\right)^{p+1}}+\frac{b y_{n}^{(p)}}{p !}+\frac{y_{n}^{(p+1)}}{(p+1) !}\right) \\
& +O\left(h^{p+2}\right)
\end{aligned}
$$

where $y_{n}=y\left(x_{n}\right), y_{n}^{\prime}=y^{\prime}\left(x_{n}\right), y_{n}^{(p)}=y^{(p)}\left(x_{n}\right)$ and $y_{n}^{(p+1)}=y^{(p+1)}\left(x_{n}\right)$ by the localizing assumption. We note that the LTE formula (15) is valid provided that $y_{n}=y\left(x_{n}\right) \neq 0$. The parameters $b$ and $c$ in formula (15) are determined from formulae (12) and (13), respectively.

\section{ABSOLUTE STABILITY ANALYSIS OF MODIFIED EXPONENTIAL-RATIONAL METHOD}

The absolute stability analysis of a $p$-MERM can be obtained easily by applying the formulae (4) and (10) - (13) to the Dahlquist's test problem in (2). It can be shown that, the application of a $p$-MERM (4) to the Dahlquist's test problem resulted in the following difference equation:

$$
y_{n+1}=R(z) y_{n}, z=h \lambda \text {. }
$$

We note that $R(z)$ is the stability function of a $p$-MERM. Clearly $y_{n} \rightarrow 0$ as $n \rightarrow \infty$ if and only if

$$
|R(z)|<1
$$

A $p$-MERM is absolutely stable for those values of $z$ for which the condition in (17) holds. The region of absolute stability of a $p$-MERM is defined as $\{z \in \square:|R(z)| \leq 1\}$ or the set of points in the complex plane such that the approximated solution remains bounded after many steps of integrations (Butcher 2008).

On applying the Dahlquist's test, (2) to formulae (10) - (13) and simplifying them using MATHEMATICA 8.0 software, we arrive at the following results:

$$
\left\{a_{0}=0, a_{j}=0, b=0, c=y_{n}\right\} .
$$

Then, apply the test (2) to formula (4) and also substitute the results in (18) into formula (4) to yield the following:

$$
\begin{aligned}
y_{n+1} & =\frac{\sum_{j=0}^{k} a_{j} h^{j}+c e^{\frac{h y_{n}^{\prime}}{y_{n}}}}{1+b h} \\
& =\frac{a_{0}+\sum_{j=1}^{k} a_{j} h^{j}+c e^{\frac{h \lambda y_{n}}{y_{n}}}}{1+b h} \\
= & e^{h \lambda} y_{n} .
\end{aligned}
$$

If we let $z=h \lambda$ in (19), then we obtain

$$
y_{n+1}=e^{z} y_{n}
$$

and according to (16), the stability function of $p$-MERM is

$$
R(z)=e^{z} .
$$

In other words, the stability function of MERM for any order of accuracy is always the function given in (20). On setting $z=x+i y$, we obtain the region of absolute stability of a $p$-MERM as shown in Figure 1.

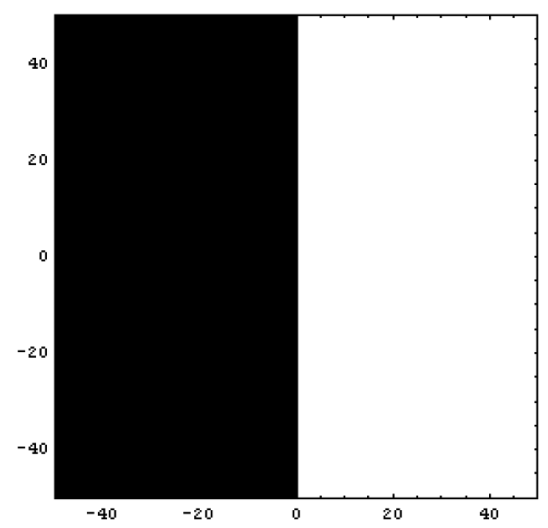

FIGURE 1. Region of absolute stability of a p-MERM

The shaded region in Figure 1 is the region of absolute stability of a $p$-MERM, where the condition $|R(z)| \leq 1$ is satisfied. From Figure 1, we can see that the region of absolute stability of a $p$-MERM contains the whole left- 
hand half plane, which show that any $p$-th order MERM is $A$-stable. In addition, on using MATHEMATICA 8.0, we have found out that $|R(z)| \rightarrow 0$ as $\operatorname{Re}(z) \rightarrow-\infty$. This shows that any $p$-th order MERM is also $L$-stable.

\section{CONSISTENCY AND CONVERGENCE ANALYSES OF MODIFIED EXPONENTIAL-RATIONAL METHOD}

We now show that any $p$-th order MERM is consistent with the differential in (1) by the following definition.

Definition 3 The MERM (4) is said to be consistent if (7) satisfy

$$
\lim _{\substack{x \rightarrow \infty \\ x=a+n h}} \frac{1}{h} L\left[y\left(x_{n}\right) ; h\right]_{p-\text { MERM }}=0 .
$$

From Definition 2, $L\left[y\left(x_{n}\right) ; h\right]_{p-\text { MERM }}$ is essentially the local truncation error for a $p$-MERM. It can be shown that the local truncation error for any $p$-th order MERM satisfy the condition in (21), which directly implies any $p$-th order MERM is consistent with the differential in (1). The following is a proof which shows that the local truncation error for any $p$-th order MERM does satisfy the condition in (21):

$$
\begin{aligned}
& \lim _{\substack{h \rightarrow 0 \\
x=a+n h}} \frac{1}{h} L\left[y\left(x_{n}\right) ; h\right]_{p-\text { MERM }} \\
& =\lim _{\substack{h \rightarrow 0 \\
x=a+n h}} \frac{1}{h}\left(h^{p+1}\left(-\frac{c\left(y_{n}^{\prime}\right)^{p+1}}{(p+1) !\left(y_{n}\right)^{p+1}}+\frac{b y_{n}^{(p)}}{p !}+\frac{y_{n}^{(p+1)}}{(p+1) !}\right)+O\left(h^{p+2}\right)^{\prime}\right) \\
& =\lim _{\substack{h \rightarrow 0 \\
x=a+n h}} h^{p}\left(-\frac{c\left(y_{n}^{\prime}\right)^{p+1}}{(p+1) !\left(y_{n}\right)^{p+1}}+\frac{b y_{n}^{(p)}}{p !}+\frac{y_{n}^{(p+1)}}{(p+1) !}+O(h)\right) \\
& =0 .
\end{aligned}
$$

Lastly, according to Fatunla (1988), the convergence of a $p$-MERM can be verified, since its application to the Dahlquist's test, (2) results in the following difference equation:

$$
y_{n}=\left(e^{h \lambda}\right)^{n} y_{0}
$$

We note that (22) is derived from (19). From (22), since $\left(e^{h \lambda}\right)^{n} \rightarrow 0$ as $n \rightarrow \infty$ for all $h \lambda$ with $\operatorname{Re}(\lambda)<0$, we have $y_{n} \rightarrow 0$ as $n \rightarrow \infty$ which, in the limit, does satisfy,

$$
\lim _{\substack{n \rightarrow \infty \\ h \rightarrow 0}} y_{n}=y\left(x_{n}\right) .
$$

This is because the theoretical solution of test (2) also behaves like $y\left(x_{n}\right) \rightarrow 0$ as $n \rightarrow \infty$. In other words, both $y_{n}$ and $y\left(x_{n}\right)$ approach zero as $n$ approaches infinity.

\section{NUMERICAL EXPERIMENTS AND COMPARISONS}

According to Teh and Yaacob (2013b), rational methods suggested by Ikhile (2001), Lambert and Shaw (1965), Teh and Yaacob (2013b) and van Niekerk $(1988,1987)$ face no difficulty in solving initial value problem (1) whose initial condition $y(a)=\eta=0$. As for the MERMs given by formula (4), it is very obvious that a $p$-th order MERM is not designed to solve initial value problem with initial condition zero because the exponential function will be undefined.

We choose to compare the third order MERM with existing third order rational methods from Ikhile (2001), Lambert and Shaw (1965), Teh and Yaacob (2013b) and van Niekerk $(1988,1987)$. Third order rational methods are chosen due to simplicity, the requirement of less evaluations of higher derivatives and less computational time. Some test problems are used to check the accuracy of these third order rational methods with different number of integration steps. We present the maximum absolute relative errors over the integration interval given by $\max _{0 \leq n \leq N}\left\{\left|y\left(x_{n}\right)-y_{n}\right|\right\}$ where $N$ is the number of integration steps. We note that $y\left(x_{n}\right)$ and $y_{n}$ represents the theoretical solution and numerical solution of a test problem at point $x_{n}$.

We present the third order rational methods that are involved in the following numerical experimentation and comparisons. Firstly, the new third order MERM, or 3-MERM:

$$
y_{n+1}=\frac{a_{0}+a_{1} h+c e^{\frac{h y^{\prime} n}{y_{n}}}}{1+b h}, 1+b h \neq 0,
$$

with

$$
\left\{\begin{array}{l}
a_{0}=y_{n}-\frac{\left(y_{n}\right)^{3}\left(-3\left(y_{n}^{\prime \prime}\right)^{2}+2 y_{n}^{\prime} y_{n}^{\prime \prime \prime}\right)}{\left(y_{n}^{\prime}\right)^{2}\left(2\left(y_{n}^{\prime}\right)^{2}-3 y_{n} y_{n}^{\prime \prime}\right)}, \\
c=\frac{\left(y_{n}\right)^{3}\left(-3\left(y_{n}^{\prime \prime}\right)^{2}+2 y_{n}^{\prime} y_{n}^{\prime \prime \prime}\right)}{\left(y_{n}^{\prime}\right)^{2}\left(2\left(y_{n}^{\prime}\right)^{2}-3 y_{n} y_{n}^{\prime \prime}\right)}, \\
a_{1}=-\frac{-2\left(y_{n}^{\prime}\right)^{4}+4 y_{n}\left(y_{n}^{\prime}\right)^{2} y_{n}^{\prime \prime}-3\left(y_{n}\right)^{2}\left(y_{n}^{\prime \prime}\right)^{2}+\left(y_{n}\right)^{2} y_{n}^{\prime} y_{n}^{\prime \prime \prime}}{y_{n}^{\prime}\left(2\left(y_{n}^{\prime}\right)^{2}-3 y_{n} y_{n}^{\prime \prime}\right)}, \\
b=-\frac{y_{n}^{\prime} y_{n}^{\prime \prime}-y_{n} y_{n}^{\prime \prime \prime}}{2\left(y_{n}^{\prime}\right)^{2}-3 y_{n} y_{n}^{\prime \prime}}
\end{array}\right\} .
$$

The third order rational method by Lambert and Shaw (1965) is given by

$$
y_{n+1}=y_{n}+h y_{n}^{\prime}+\frac{h^{2}}{2} y_{n}^{\prime \prime}+\frac{h^{3}}{2} \frac{y_{n}^{\prime \prime} y_{n}^{\prime \prime \prime}}{3 y_{n}^{\prime \prime}-h y_{n}^{\prime \prime \prime}} .
$$

The third order rational methods by van Niekerk $(1988,1987)$ are given by

$$
\begin{aligned}
y_{n+1}= & y_{n}+\frac{h y_{n} y_{n}^{\prime}}{y_{n}-h y_{n}^{\prime}} \\
+ & \frac{3 h^{2}\left(-2\left(y_{n}^{\prime}\right)^{2}+y_{n} y_{n}^{\prime \prime}\right)^{2}}{\left(-y_{n}+h y_{n}^{\prime}\right)\left(\begin{array}{l}
12\left(y_{n}^{\prime}\right)^{2}-6 y_{n} y_{n}^{\prime \prime}-6 h y_{n}^{\prime} y_{n}^{\prime \prime} \\
+3 h^{2}\left(y_{n}^{\prime \prime}\right)^{2}+2 h y_{n} y_{n}^{\prime \prime \prime}-2 h^{2} y_{n}^{\prime} y_{n}^{\prime \prime \prime}
\end{array}\right)},
\end{aligned}
$$


and

$$
y_{n+1}=y_{n}+h y_{n}^{\prime}+\frac{h^{2}}{2} y_{n}^{\prime \prime}+\frac{h^{3}}{2} \frac{y_{n}^{\prime \prime} y_{n}^{\prime \prime \prime}}{3 y_{n}^{\prime \prime}-h y_{n}^{\prime \prime \prime}},
$$

respectively. From formulae (25) and (27), we note that the third order rational methods of Lambert and Shaw (1965) and van Niekerk (1988) are identical. The third order rational methods from Ikhile (2001) is given by

$$
y_{n+1}=y_{n}+\frac{12 h\left(y_{n}^{\prime}\right)^{3}}{12\left(y_{n}^{\prime}\right)^{2}-6 h y_{n}^{\prime} y_{n}^{\prime \prime}+h^{2}\left[3\left(y_{n}^{\prime \prime}\right)^{2}-2 y_{n}^{\prime} y_{n}^{\prime \prime \prime}\right]} \text {. }
$$

Lastly, the two third order exponential-rational methods (ERMs) from Teh and Yaacob (2013b) denoted by $3-\operatorname{ERM}(1)$ and 3-ERM(2) are:

$$
y_{n+1}=\frac{a_{0}+c_{1} e^{c_{2} h}}{1+b h}, 1+b h \neq 0,
$$

with

$$
\begin{aligned}
& \left\{a_{0}=y_{n}-\frac{-2\left(y_{n}^{\prime}\right)^{2}+y_{n} y_{n}^{\prime \prime}}{c_{2}\left(c_{2} y_{n}-2 y_{n}^{\prime}\right)}, b=\frac{c_{2} y_{n}^{\prime}-y_{n}^{\prime \prime}}{-c_{2} y_{n}+2 y_{n}^{\prime}},\right. \\
& \left.c_{1}=\frac{-2\left(y_{n}^{\prime}\right)^{2}+y_{n} y_{n}^{\prime \prime}}{c_{2}\left(c_{2} y_{n}-2 y_{n}^{\prime}\right)}, c_{2}=\frac{-3 y_{n}^{\prime} y_{n}^{\prime \prime}+y_{n} y_{n}^{\prime \prime \prime}-U}{2\left(-2\left(y_{n}^{\prime}\right)^{2}+y_{n} y_{n}^{\prime \prime}\right)}\right\} ;
\end{aligned}
$$

and

$$
y_{n+1}=\frac{a_{0}+c_{1} e^{c_{2} h}}{1+b h}, 1+b h \neq 0,
$$

with

$$
\begin{gathered}
\left\{a_{0}=y_{n}-\frac{-2\left(y_{n}^{\prime}\right)^{2}+y_{n} y_{n}^{\prime \prime}}{c_{2}\left(c_{2} y_{n}-2 y_{n}^{\prime}\right)}, b=\frac{c_{2} y_{n}^{\prime}-y_{n}^{\prime \prime}}{-c_{2} y_{n}+2 y_{n}^{\prime}},\right. \\
\left.c_{1}=\frac{-2\left(y_{n}^{\prime}\right)^{2}+y_{n} y_{n}^{\prime \prime}}{c_{2}\left(c_{2} y_{n}-2 y_{n}^{\prime}\right)}, c_{2}=\frac{-3 y_{n}^{\prime} y_{n}^{\prime \prime}+y_{n} y_{n}^{\prime \prime \prime}+U}{2\left(-2\left(y_{n}^{\prime}\right)^{2}+y_{n} y_{n}^{\prime \prime}\right)}\right\},
\end{gathered}
$$

respectively. We note that

$$
U=\sqrt{\left(3 y_{n}^{\prime} y_{n}^{\prime \prime}-y_{n} y_{n}^{\prime \prime \prime}\right)^{2}-4\left(-2\left(y_{n}^{\prime}\right)^{2}+y_{n} y_{n}^{\prime \prime}\right)\left(-3\left(y_{n}^{\prime \prime}\right)^{2}+2 y_{n}^{\prime} y_{n}^{\prime \prime}\right)} .
$$

\section{Problem 1}

$$
y^{\prime}(x)=-2 y(x)+4 x, y(0)=3, x \in[0,0.5] .
$$

The theoretical solution is $y(x)=4 e^{-2 x}-1+2 x$.

\section{Problem 2 (Fatunla 1982)}

$$
y^{\prime}(x)=-2000 e^{-200} x+9 e^{-x}+x e^{-x}, y(0)=10, x \in[0,10] .
$$

The theoretical solution is $\mathrm{y}(\mathrm{x})$.
Problem 3 (Ramos 2007)

$$
\begin{aligned}
& y_{1}^{\prime}(x)=-1002 y_{1}(x)+1000 y_{2}(x)^{2}, y_{1}(0)=1, x \in[0,1] ; \\
& y_{2}^{\prime}(x)=y_{1}(x)-y_{2}(x)\left(1+y_{2}(x)\right), y_{2}(0)=1, x \in[0,1] ;
\end{aligned}
$$

The theoretical solutions are $y_{1}(x)=e^{-2 x}$ and $y_{2}(x)=e^{-x}$.

Problem 4 (Yaakub \& Evans 2003)

$$
\begin{aligned}
& y^{\prime \prime}(x)+101 y^{\prime}(x)+100 y(x)=0, y(0)=1.01, \\
& y^{\prime}(0)=-2, x \in[0,10] .
\end{aligned}
$$

The theoretical solution is $y(x)=e^{-2 x}$ and $y_{2}(x)=$ $e^{-x}$. Problem 4 can be reduced to a system of first order differential equations, i.e.

$$
\begin{aligned}
& y_{1}^{\prime}(x)=y_{2}(x), y_{1}(0)=1.01, x \in[0,10] \\
& y_{2}^{\prime}(x)=-100 y_{1}(x)-1.01 y_{2}, y_{2}(0)=-2, x \in[0,10] .
\end{aligned}
$$

The theoretical solutions are $y_{1}(x)=0.01 e^{-100 x}+e^{-x}$ and $y_{2}(x)=-e^{-100 x}-e^{-x}$.

\section{Problem 5 (Ramos 2007)}

$$
y^{\prime}(x)=1+y(x)^{2}, y(0)=1, x \in[0,0.8] .
$$

The theoretical solution is $y(x)=\tan (x+\pi / 4)$. Problem 5 is an example of problem whose solution possesses singularity. From the theoretical solution, notice that the solution becomes unbounded in the neighbourhood of the singularity at $x=\pi / 4 \approx 0.785398163367448$.

From Table 1, we can see that the third order rational method of Ikhile (2001) and van Niekerk (1987) generated the least accurate numerical results, while the remaining third order rational methods by Lambert and Shaw (1965) and van Niekerk (1988) are found to have comparable accuracy in solving Problem 1. Our new 3-MERM turned out to have better accuracy compared with other existing third order rational methods. The third order methods $3-\operatorname{ERM}(1)$ and 3-ERM(2) are unable to return any result because this problem causes the expressions $c_{2}$ in (29) and (30) to become undefined.

Problem 2 is indeed a very stiff, non-autonomous problem. From Table 2, we can see that 3-MERM and 3-ERM(1) generated results that are comparable in accuracy for $N=$ 10000 and $N=100000$ in solving Problem 2, followed by 3-ERM(2). Third order rational methods by Ikhile (2001), Lambert and Shaw (1965) and van Niekerk $(1988,1987)$ are found to have comparable accuracy for $N=1000,10000$ and 100000 , except for Ikhile (2001) which converged slowly to the exact solution for $N=100000$.

Problem 3 is a stiff system, but less 'stiffer' than Problem 2. From Tables 3 and 4, we can see that 3 -ERM(1) generated 
TABLE 1. Maximum absolute relative errors of various third order methods with respect to the number of steps (Problem 1)

\begin{tabular}{|c|c|c|c|c|c|c|c|}
\hline$N$ & $\begin{array}{c}\text { Lambert \& } \\
\text { Shaw (1965) }\end{array}$ & $\begin{array}{c}\text { Van Niekerk } \\
\text { (1987) }\end{array}$ & $\begin{array}{c}\text { Van Niekerk } \\
\text { (1988) }\end{array}$ & $\begin{array}{l}\text { Ikhile } \\
\text { (2001) }\end{array}$ & 3-ERM(1) & 3-ERM(2) & 3-MERM \\
\hline 16 & $5.07503(-06)$ & $3.25864(-04)$ & $5.07503(-06)$ & $5.84945(-05)$ & - & - & $4.24138(-07)$ \\
\hline 32 & $6.28976(-07)$ & $2.93414(-05)$ & $6.28976(-07)$ & $7.85013(-06)$ & - & - & $5.28343(-08)$ \\
\hline 64 & $7.82908(-08)$ & $3.83339(-06)$ & $7.82908(-08)$ & $1.01742(-06)$ & - & - & $6.58942(-09)$ \\
\hline
\end{tabular}

TABLE 2. Maximum absolute relative errors of various third order methods with respect to the number of steps (Problem 2)

\begin{tabular}{cccccccc}
\hline$N$ & $\begin{array}{c}\text { Lambert \& } \\
\text { Shaw }(1965)\end{array}$ & $\begin{array}{c}\text { Van Niekerk } \\
(1987)\end{array}$ & $\begin{array}{c}\text { Van Niekerk } \\
(1988)\end{array}$ & $\begin{array}{c}\text { Ikhile } \\
(2001)\end{array}$ & 3-ERM(1) & 3-ERM(2) & 3-MERM \\
\hline 100 & $7.08987(+01)$ & $1.51505(+00)$ & $7.08987(+01)$ & $4.71235(+00)$ & $8.05125(-01)$ & $8.05075(-01)$ & $2.51013(-02)$ \\
1000 & $7.48249(-01)$ & $3.57558(-01)$ & $7.48249(-01)$ & $6.24419(-02)$ & $2.36491(-02)$ & $1.43271(-01)$ & $8.52263(-03)$ \\
10000 & $1.06282(-03)$ & $1.44188(-03)$ & $1.06282(-03)$ & $1.34363(-03)$ & $2.76633(-05)$ & $1.93116(-04)$ & $2.67342(-05)$ \\
100000 & $1.10728(-06)$ & $1.89317(-06)$ & $1.10728(-06)$ & $1.44295(-05)$ & $2.86579(-08)$ & $6.40614(-07)$ & $3.33494(-08)$ \\
\hline
\end{tabular}

TABLE 3. Maximum absolute relative errors of various third order methods with respect to the number of steps $\left(y_{1}(x)\right)($ Problem 3$)$

\begin{tabular}{cccccccc}
\hline$N$ & $\begin{array}{c}\text { Lambert \& } \\
\text { Shaw (1965) }\end{array}$ & $\begin{array}{c}\text { Van Niekerk } \\
(1987)\end{array}$ & $\begin{array}{c}\text { Van Niekerk } \\
(1988)\end{array}$ & $\begin{array}{c}\text { Ikhile } \\
(2001)\end{array}$ & 3-ERM(1) & 3-ERM(2) & 3-MERM \\
\hline 160 & $2.19212(+02)$ & $3.17981(-01)$ & $2.19212(+02)$ & $8.23205(-03)$ & $5.19877(-05)$ & $3.96606(+01)$ & $2.64155(+00)$ \\
320 & $2.90442(-05)$ & $3.84679(-05)$ & $2.90442(-05)$ & $1.34220(-03)$ & $1.99991(-06)$ & $3.28414(-06)$ & $8.10996(-06)$ \\
640 & $2.01537(-11)$ & $2.01373(-11)$ & $2.01537(-11)$ & $4.49640(-15)$ & $4.21885(-15)$ & $4.10783(-15)$ & $4.05231(-15)$ \\
\hline
\end{tabular}

TABLE 4. Maximum absolute relative errors of various third order methods with respect to the number of steps $\left(y_{2}(x)\right)($ Problem 3$)$

\begin{tabular}{cccccccc}
\hline$N$ & $\begin{array}{c}\text { Lambert \& } \\
\text { Shaw (1965) }\end{array}$ & $\begin{array}{c}\text { Van Niekerk } \\
(1987)\end{array}$ & $\begin{array}{c}\text { Van Niekerk } \\
(1988)\end{array}$ & $\begin{array}{c}\text { Ikhile } \\
(2001)\end{array}$ & 3-ERM(1) & 3-ERM(2) & 3-MERM \\
\hline 160 & $2.18514(-01)$ & $5.06153(-04)$ & $2.18514(-01)$ & $5.28030(-03)$ & $3.14264(-05)$ & $4.72343(-02)$ & $2.00709(-04)$ \\
320 & $2.16581(-06)$ & $2.16300(-06)$ & $2.16581(-06)$ & $7.00650(-05)$ & $1.86383(-07)$ & $6.49753(-07)$ & $6.70213(-07)$ \\
640 & $1.96714(-11)$ & $1.96536(-11)$ & $1.96714(-11)$ & $4.10783(-15)$ & $2.77556(-15)$ & $2.33147(-15)$ & $2.88658(-15)$ \\
\hline
\end{tabular}

satisfying results for $N=160$ compared to other third order rational methods. In view of this, we can say that $3-\operatorname{ERM}(1)$ has potential to achieve high accuracy with a smaller number of integration steps. 3-MERM and 3-ERM(2) are only found to have comparable accuracy for $N=320$ and $N=640$. Numerical results generated by the third order rational methods of Lambert and Shaw (1965) and van Niekerk $(1988,1987)$ are less satisfying for $N=160$ especially when computing the component $y_{1}(x)$.

Problem 4 is a stiff system arises from the reduction of a second order initial value problem to a system of coupled first order differential equations. From Table 5, it can be seen that 3-MERM, 3-ERM(1), third order rational methods of Lambert and Shaw (1965), van Niekerk (1988) and Ikhile (2001) are found to have comparable accuracy except for $N=1280$. On the other hand, 3-ERM(2) and third order method of van Niekerk (1987) are found to have comparable accuracy in solving Problem 4 for any number of integration steps.

Lastly, the results from Table 6 clearly shows that the third order rational method of Ikhile (2001) is the most suitable method in solving a problem whose solution possesses singularity because it yields more accurate numerical results. 3-MERM, 3-ERM(2) and the third order rational method of van Niekerk (1987) are comparable in accuracy; while the third order rational methods of Lambert and Shaw (1965) and van Niekerk (1988) are comparable. 3-ERM(1) returns the least satisfying results among all third order rational methods.

\section{CONCLUSION}

In this paper, we have presented a new class of modified exponential-rational methods (MERMs) which are explicit one-step methods that are based on rational functions. The general formulation of MERM is given in (4) while the order condition and local truncation error for a MERM are explained in Definition 1 and Definition 2. The parameters $b, c$ and $a$ for $j=0,1, \ldots, k$ are generalized in which the generalized formulae were shown in (10) - (13). On choosing an integer of $p \geq 2$ (i.e. the order of a MERM), the parameters for a specific MERM can be determined and these parameters are 
TABLE 5. Maximum absolute relative errors of various third order methods with respect to the number of steps (Problem 4$)$

\begin{tabular}{cccccccc}
\hline$N$ & $\begin{array}{c}\text { Lambert \& } \\
\text { Shaw (1965) }\end{array}$ & $\begin{array}{c}\text { Van Niekerk } \\
(1987)\end{array}$ & $\begin{array}{c}\text { Van Niekerk } \\
(1988)\end{array}$ & $\begin{array}{c}\text { Ikhile } \\
(2001)\end{array}$ & 3-ERM(1) & 3-ERM(2) & 3-MERM \\
\hline 1280 & $2.91323(-05)$ & $1.67276(-04)$ & $2.91323(-05)$ & $2.15408(-05)$ & $7.46251(-04)$ & $1.68219(-04)$ & $3.74217(-05)$ \\
2560 & $3.12721(-06)$ & $1.56050(-05)$ & $3.12721(-06)$ & $3.18139(-06)$ & $3.31054(-06)$ & $2.48349(-05)$ & $4.58719(-06)$ \\
5120 & $3.67925(-07)$ & $1.24983(-06)$ & $3.67925(-07)$ & $4.38761(-07)$ & $1.96674(-07)$ & $1.16168(-06)$ & $5.65849(-07)$ \\
\hline
\end{tabular}

TABLE 6. Maximum absolute relative errors of various third order methods with respect to the number of steps (Problem 5)

\begin{tabular}{cccccccc}
\hline$N$ & $\begin{array}{c}\text { Lambert \& } \\
\text { Shaw (1965) }\end{array}$ & $\begin{array}{c}\text { Van Niekerk } \\
(1987)\end{array}$ & $\begin{array}{c}\text { Van Niekerk } \\
(1988)\end{array}$ & $\begin{array}{c}\text { Ikhile } \\
(2001)\end{array}$ & 3-ERM(1) & 3-ERM(2) & 3-MERM \\
\hline 16 & $2.39514(-02)$ & $2.10235(-01)$ & $2.39514(-02)$ & $5.20857(-04)$ & $3.93191(+00)$ & $1.51616(-01)$ & $4.46280(-01)$ \\
32 & $5.73126(-03)$ & $5.01590(-02)$ & $5.73126(-03)$ & $6.22138(-05)$ & $5.87270(+00)$ & $3.47699(-02)$ & $9.22318(-02)$ \\
64 & $1.72803(-02)$ & $2.15491(-01)$ & $1.72803(-02)$ & $9.67085(-05)$ & $4.01475(+00)$ & $1.52879(-01)$ & $3.74109(-01)$ \\
\hline
\end{tabular}

unique for a chosen integer. The principal local truncation error term is also generalized as in (15). Absolute stability analysis showed that a $p$-MERM is $L$-stable. A $p$-MERM is also said to be consistent by Definition 3 and convergence for any order or accuracy. An example of MERM was introduced i.e. 3-MERM, given in (24).

We have chosen some test problems to evaluate the effectiveness of MERMs and other existing rational methods in terms of numerical accuracy. From the numerical experiments conducted, MERMs and ERMs from Teh and Yaacob (2013b) are found to have comparable accuracy and they generated more accurate numerical results compared with existing rational methods of Ikhile (2001), Lambert and Shaw (1965) and van Niekerk $(1988,1987)$ in solving non-stiff problem (Problem 1) and stiff problems (Problems 2,3 and 4). All these tests seem to indicate that MERMs are suitable and more reliable for general initial value problems whose solutions possess no singularities. However, MERMs are not suitable for problems whose solutions possess singularities, as was shown in Table 6. Finally, MERMs and ERMs of Teh and Yaacob (2013b) are comparable in terms of numerical accuracy. However, we suggest MERMs over ERMs for the numerical solution of first order initial value problem because MERMs are uniquely defined but ERMs are not uniquely defined as explained in the introduction.

\section{REFERENCES}

Butcher, J.C. 2008. Numerical Methods for Ordinary Differential Equations. 2nd ed. West Sussex: John Wiley \& Sons, Ltd.

Fatunla, S.O. 1988. Numerical Methods for Initial Value Problems in Ordinary Differential Equations. San Diego: Academic Press, Inc.

Fatunla, S.O. 1986. Numerical treatment of singular initial value problems. Computers and Mathematics with Applications 12B(5/6): 1109-1115.

Fatunla, S.O. 1982. Non-linear multistep methods for initial value problems. Computers and Mathematics with Applications 8(3): 231-239.

Ikhile, M.N.O. 2004. Coefficients for studying one-step rational schemes for IVPs in ODEs: III. Computers and Mathematics with Applications 47: 1463-1475.
Ikhile, M.N.O. 2002. Coefficients for studying one-step rational schemes for IVPs in ODEs: II. Computers and Mathematics with Applications 44: 545-557.

Ikhile, M.N.O. 2001. Coefficients for studying one-step rational schemes for IVPs in ODEs: I. Computers and Mathematics with Applications 41: 769-781.

Lambert, J.D. 1991. Numerical Methods for Ordinary Differential Systems. Chichester: John Wiley \& Sons, Ltd.

Lambert, J.D. 1974. Two unconventional classes of methods for stiff systems. In Stiff Differential Equations, edited by Willoughby, R.A. New York: Plenum Press.

Lambert, J.D. 1973. Computational Methods in Ordinary Differential Equations. London: John Wiley \& Sons, Ltd.

Lambert, J.D. \& Shaw, B. 1965. On the numerical solution of $y^{\prime}=$ $f(x, y)$ by a class of formulae based on rational approximation. Mathematics of Computation 19(91): 456-462.

Luke, Y.L., Fair, W. \& Wimp, J. 1975. Predictor-corrector formulas based on rational interpolants. Computers and Mathematics with Applications 1(1): 3-12.

Okosun, K.O.\& Ademiluyi, R.A. 2007a. A two-step second order inverse polynomial methods for integration of differential equations with singularities. Research Journal of Applied Sciences 2(1): 13-16.

Okosun, K.O. \& Ademiluyi, R.A. 2007b. A three step rational methods for integration of differential equations with singularities. Research Journal of Applied Sciences 2(1): 84-88.

Ramos, H. 2007. A non-standard explicit integration scheme for initial-value problems. Applied Mathematics and Computation 189: 710-718.

Teh, Y.Y. \& Yaacob, N. 2013a. A new class of rational multistep methods for solving initial value problem. Malaysian Journal of Mathematical Sciences 7(1): 31-57.

Teh, Y.Y. \& Yaacob, N. 2013b. One-step exponential-rational methods for the numerical solution of first order initial value problems. Sains Malaysiana 42(6): 845-853.

Teh, Y.Y., Yaacob, N. \& Alias, N. 2011. A new class of rational multistep methods for the numerical solution of first order initial value problems. Matematika 27(1): 59-78.

Teh, Y.Y., Yaacob, N. \& Alias, N. 2009. Numerical comparison of some explicit one-step rational methods in solving initial value problems. Paper presented at the 5th Asian Mathematical Conference. 22-26 June. Kuala Lumpur, Malaysia. 
van Niekerk,F.D. 1988. Rational one-step methods for initial value problems. Computers and Mathematics with Applications 16(12): 1035-1039.

van Niekerk, F.D. 1987. Non-linear one-step methods for initial value problems. Computers and Mathematics with Applications 13(4): 367-371.

Wambecq, A. 1976. Nonlinear methods in solving ordinary differential equations. Journal of Computational and Applied Mathematics 2(1): 27-33.

Wu, X.Y. \& Xia, J.L. 2001. Two low accuracy methods for stiff systems. Applied Mathematics and Computation 123: 141-153.

Yaacob, N., Teh, Y.Y. \& Alias, N. 2010. A new class of 2-step rational multistep methods. Jurnal KALAM 3(2): 26-39.

Yaakub, A.R. \& Evans, D.J. 2003. New L-stable modified trapezoidal methods for the initial value problems. International Journal of Computer Mathematics 80(1): 95-104.
School of Quantitative Sciences, College of Arts and Sciences Universiti Utara Malaysia

06010 UUM Sintok, Kedah Darul Aman

Malaysia

*Corresponding author; email: yuanying@uum.edu.my

Received: 1 January 2014

Accepted: 17 April 2014 